\title{
The strange case of the Turkish and Venetian judges in eighteenth-century Mani wall paintings
}

\author{
John Chapman
}

University of Hertfordshire

Investigating church wall paintings in Mani, Greece, the author identified a common theme of the Ainoi, the graphic interpretation of Psalms 148-150. Within this scheme there is often a specific depiction of the 'Judges of the Earth' as an Ottoman judge and a Venetian nobleman. This depiction is unique to Mani and is restricted to the mid-eighteenth century and those areas of Mani dominated by the rule of the kapetanoi. The paintings allude to the lack of established legal systems in that period of Mani's history and refer back to times of stable law under Ottoman and Venetian rule.

Mani, the rusted middle prong of the trident of peninsulas of the southern Peloponnese, has attracted the attention of many who wish, for a variety of impulses and purposes, to claim for it an independence and separateness that it may or may not deserve. Locals will eagerly point out the symbolic and semantic difference of the wording on the Maniat

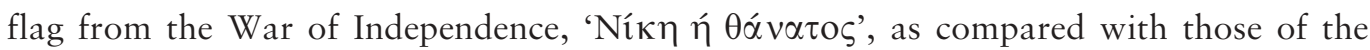

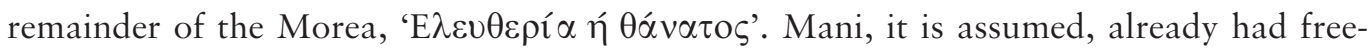
dom and independence from the Ottomans and had mere need of victory (or death). These assertions, which range from the instinctive and populist to the arcane and erudite, tend to cloud a more complex and sometimes unexplored association with Hellenic traditions and history. This study, I hope, sheds some flickering torchlight on a few un-noted corners of Mani's past. ${ }^{1}$

One thing obvious to any visitor to Mani is the plethora of churches, chapels and monasteries that dot the landscape. The architectural characteristics and wall paintings of these buildings have fascinated generations of scholars and amateurs alike. The first, brief investigations by curious researchers from the pre-First World War survey of Lakonia by the British School at Athens were undertaken by Traquair and Dawkins, ${ }^{2}$ followed in the

1 The author owes many debts of gratitude in the development of this paper, but two individuals need especial recognition: Bob Barrow and Professor Anthony Bryer. The former and I fretted enjoyably over the field evidence, and without the latter's unstinting encouragement and guidance this paper would never have seen this academic light of day.

2 R. Traquair, 'Laconia III: the churches of Western Mani' ABSA 15 (1908-9) 177-213. 
interwar years by $\mathrm{Megaw}^{3}$ and more recently by such eminent Greek scholars as Drandakis and his colleagues. ${ }^{4}$ The churches of Mani, enumerated in their hundreds by books and travelogues (Kassis lists over 1,500), ${ }^{5}$ possess a particular resonance for lovers of Mani.

I have approached Mani in the same spirit, searching out and photographing churches, enquiring after keys and puzzling over the date and authorship of the wall paintings. Of particular interest is a wall painting in the late eighteenth-century church of the Zoodochos Pigi just below the summit of the castle of Zarnata in Exo (Outer) Mani. The scene, now familiar, was difficult to see in the gloom of the windowless church. At first I interpreted it as a wedding ceremony, under a domed canopy, between a flaxen-haired beauty and a turbaned wealthy bearded Ottoman with a wand topped with a crescent. The ceremony is flanked by dancing women and musicians. Odd, I thought, in an area that prided itself on being independent of Turkish rule. Closer scrutiny revealed that the 'bride' was in fact an eighteenth-century Western gentleman carrying a cane (in some other cases topped with a cross). On his head was an approximation of a tricorn hat atop a long flowing blond wig. Frock-coat and knee-breeches, stockings and buckled shoes completed the picture. This curious piece of iconography is unknown outside of Mani, although the scheme into which it fitted was prevalent throughout the Orthodox world. ${ }^{6}$

The overall scheme is the Ainoi or 'Praises', a graphical representation of the last Psalms (148-150), usually to be found in the western section of the nave of an Orthodox church. As with its Western equivalent, Lauds, it holds a particular position in the liturgy, between Matins and the Great Doxology. The division of the holy space of the Orthodox church had long been determined by practice as delineated by Symeon of Thessalonike in the fifteenth century in The Sacred Liturgy. The sanctuary was the purlieu of the priests, 'which is above the firmament and the heavens. The holy altar represents the throne of God, the Resurrection of Christ, and his venerable tomb. The nave typifies the heavens and paradise, and the far end of the nave and the narthexes represent the creation of the earth for us and all the creatures upon earth."7

The Ainoi paintings in Mani therefore are normally found in the western barrel vault of the nave, though in some instances they are located in a narthex or a northern side

3 A. Megaw, 'Byzantine architecture in Mani', ABSA 33 (1933) 137-62.

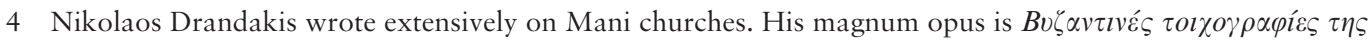

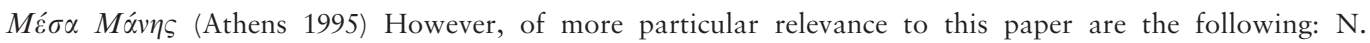

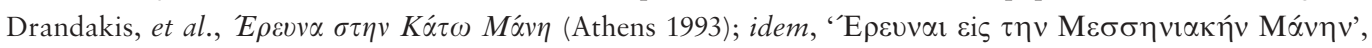

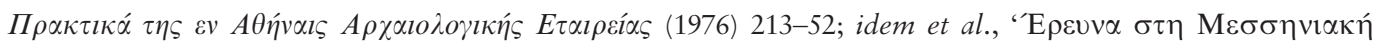

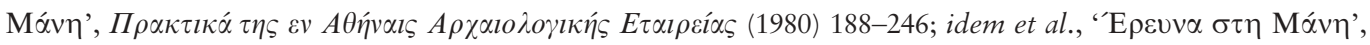

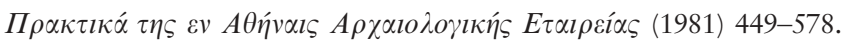

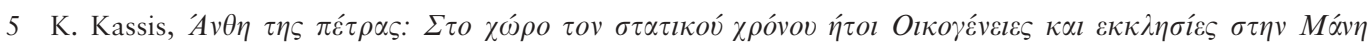
(Athens 1990).

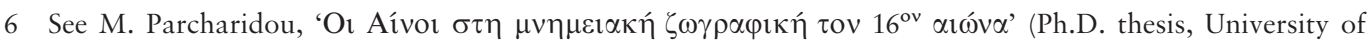
Thessaloniki 2000).

7 MPG 292A, as cited by S. Gerstel, Beholding the Sacred Mysteries: Programs of the Byzantine Sanctuary (Seattle 1999) 5. 
vault. Once one can correlate the texts on which this scheme is based to the images, many of its elements fall simply into place. At the centre of the Ainoi is a full-length Christ in Majesty, often in the barrel vault of the nave. Around this figure are circles of creatures giving praise to Him. The first circle is of Seraphim and Angels as in Psalm 148: 2, 'Praise ye him, all his angels: praise ye him, all his hosts' ${ }^{8}$ Outside of these are the signs of the zodiac representing the line in Psalm 148: 3-4, 'Praise ye him, sun and moon: praise him, all ye stars of light. Praise him, ye heavens of heavens.'

On the south barrel vault there will be representations of birds, animals and humanoids. These include domestic animals and the more exotic elephants, leopards and camels, often of a very odd order. For example the leopard in the katholikon of the monastery of the Panagia of Chelmos, near Gaitses, sports red and green spots and elephants often have overly literal trumpet-like ends to their trunks. Many of these will have been copied, albeit somewhat erroneously, from Western prints. ${ }^{9}$ Amongst them will be strange creatures from the realms of fantasy, both animal - dragons and unicorns - and humanoid: for example, men with one huge foot (Skiapodes), others with their faces on their chests (Sternophthalmoi), and dog-faced humanoids (Kynokephaloi), who probably derive from travellers' fables such as those of Sir John Mandeville, though their roots lie much further back in time. ${ }^{10}$ These creatures refer in part to Psalm 148: 10, 'Beasts, and all cattle; creeping things, and flying fowl.' In other words, all the creatures of earth should praise the Lord and one can only speculate as to the unearthly noise they would have made together. It is clear that the artists, normally restricted in their depictions by centuries of tradition, were able to allow their imagination more rein in these paintings (see Fig. 1).

On the north ceiling is a more complicated scene that includes many further references to the last Psalms. The scene is filled with musicians and dancing women in contemporary local costume, as if at a local festival. One can surmise that these are based upon local dances. Psalm 149: 3 adds: 'Let them praise his name in the dance: let them sing praises unto him with the timbrel and harp.' Although the harp survives in the paintings, other instruments played by the musicians are often more local - the lyra is often depicted - as are indigenous plucked stringed instruments.

Other scenes occur on the north wall and ceiling. Kings are depicted in chains, and threatening them with swords are armoured and often helmeted figures. This refers to the sequence in Psalm 149: 4-9: 'For the Lord taketh pleasure in his people ... Let the saints be joyful in glory ... Let the high praises of God be in their mouth, and a two-edged sword in their hand; To execute vengeance upon the heathen, and punishments upon the people; To bind their kings with chains, and their nobles with fetters of iron.'

8 All quotes from the Psalms are from the King James version of the Bible. The Septuagint versions are practically identical.

9 G. Schiemenz, 'The painted Psalms of Athos', in A. Bryer and M. Cunningham (eds), Mount Athos and Byzantine Monasticism (London 1996) 223-36.

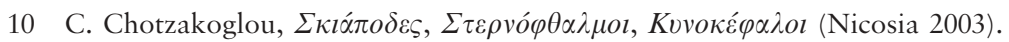




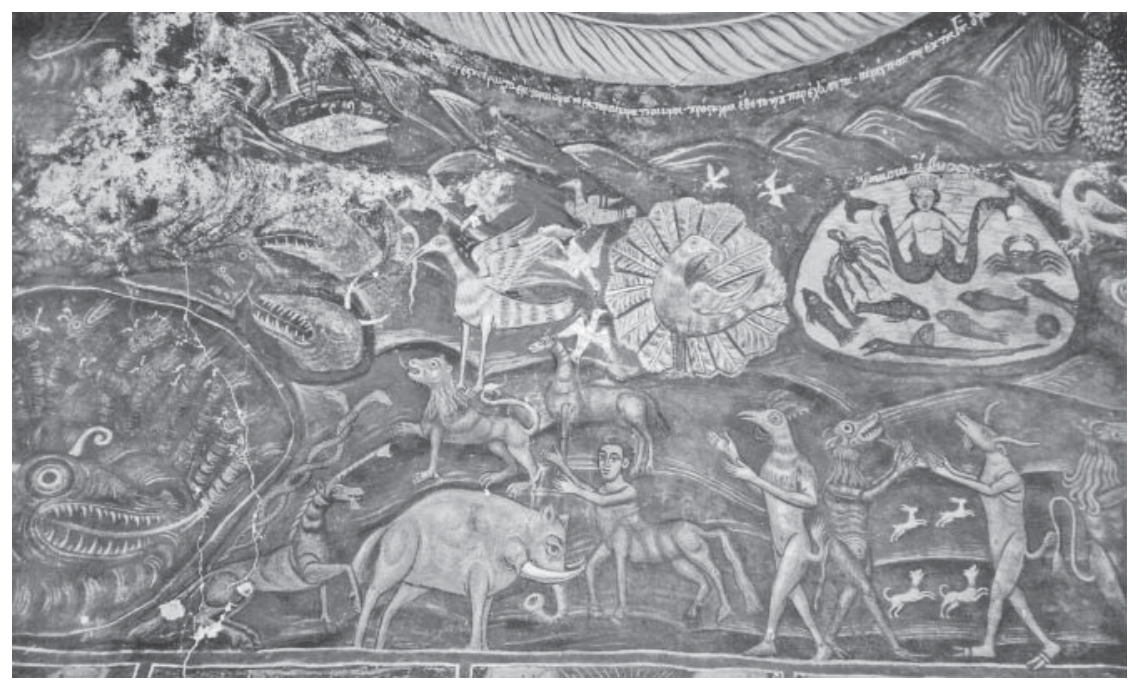

Figure 1 The Beasts of the Earth, south wall of nave. The katholikon of Profitis Ilias, monastery of Roussaki, Kalianeika, 1758

Further verses are illustrated in the background scenes: 'Fire, and hail; snow, and vapours; stormy wind fulfilling his word' (Psalm 148: 8), and in the next verse (148: 9) hills and mountains are depicted along with trees, some of which are intended to be cedars. In some Mani churches fire, hail, snow, ice and wind are sometimes portrayed in human guise - a man coming forth from a cave with a trumpet is one variation on the wind recorded in Mount Athos. However, in the katholikon of the monastery of Roussaki, near Kalianeika, these manifestations of weather are quite literally interpreted on the south ceiling, apart from wind, which is depicted, as on Athos, as the trumpet blast. These interpretations are clearly based on the tradition set by the earliest (fifteenth-century) Ainoi scheme in Mani, at Agios Nikolaos in Zarnata castle.

The scene with the canopy, with two kings or emperors in the background and the Ottoman and the Westerner seated at the front, is central to a significant number of the Ainoi paintings in Mani. Who are they? The late Miltiadis Garidis, who came from the Exo Mani village of Ano Doloi, had studied the churches of the surrounding area for his Études sur le Jugement Dernier post-byzantin du XVe à la fin $d u$ XIXe siècle: Iconographie-ésthétique, which relates:

Dans l'église de la Vierge-Source-de-Vie (1787) de la forteresse de Zarnata,... dont les peintures sont pleines d'éléments populaires et folkloriques, puisés dans la vie, les légendes et les gravures, surtout dans l'illustration des Psaumes et avec des influences italiennes apparantes dans certaines compositions, la représentation du Jugement Dernier se combine avec celle des Psaumes. Cette confusion est peut-être dûe à

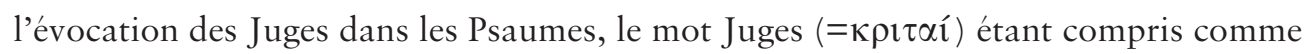
désignant des Juges dans un tribunal. Ces Juges sont représentés sous un baldaquin, 
avec des traits et des attributs imprécis d'Empereurs et princes byzantins, d'un Seigneur vénitien en costume d'époque et d'un Cadi musulman, enturbanné. ${ }^{11}$

Perhaps Garidis was too keen to identify the Last Judgement, as this was the focus of his research. But what is clear is that this is not a conflation of two schemes, but merely a mid-eighteenth-century depiction of the phrase from Psalm 148: 11, 'Kings of the earth, and all people; princes, and all judges of the earth'. The clue, as always, is in the, some-

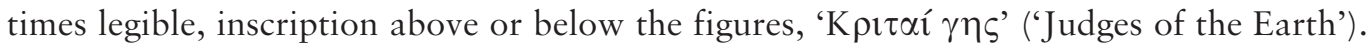
But why a Turkish and Venetian official in an area which has prided itself in its independence from outside powers? To follow this theme further we need to analyse the history of the Ainoi scheme in Mani church wall paintings, and then attempt to match this to the contemporaneous history of the peninsula.

Among the churches decorated with the Ainoi scheme in Mani, there are a number of common factors. The paintings are invariably post-Byzantine even though the church buildings often date from the medieval period and in a number of cases the Ainoi occupy a post-medieval extension such as Agios Nikolaos at Proastio and the Metamorphosis at Milia. The scheme requires a large amount of wall and ceiling space, and therefore is normally associated with a somewhat large (by Mani standards) edifice, or rather one which had local significance either as a monastery katholikon or the central, 'parish' church of a village. All the examples of the Ainoi in Mani occur in either Exo (Outer, north-west) Mani or in the area known as Kato (Lower, south-east) Mani. There are none in Mesa (Deep, south-west) Mani. Both of the former areas were, by the eighteenth century, divided into a number of districts under the domination of so-called kapetano $i$ (an imported Venetian term and position in Maniat society dating from the early 1700s). This literally means captains, but really refers to dominant and all-powerful families or clans. An exception to this geographical rule could be made for the monastery of the Panagia at Limeni, which has a much-damaged Ainoi and is, if one accepts the bay of Limeni as the dividing line between Upper and Lower Mani, in Mesa Mani. However, this monastery is within the sphere of influence, and was founded by, the powerful kapetanoi family of Mavromichalis - and, as Leake observed in 1805, the inhabitants of Limeni and Tsimova (present day Areopolis) 'are anxious to be considered separate from the remainder of Inner Mani, which forms more particularly the Kakavulia, or land of Evil Counsel'. 12

The earliest version of the Ainoi in Mani is in the church of Agios Nikolaos, in the castle of Zarnata. The fragmentary frescos of this ruined church show two distinct styles. The first, dated by Eleni Dori to the fifteenth century and ascribed to the painter Xenos Digenis, the second to the early eighteenth century and a certain Christodoulos Kalliergis

11 M. Garidis, Etudes sur le Jugement Dernier post-byzantin du XVe à la fin du XIXe siècle: iconographieesthétique (Thessaloniki 1985) 52.

12 W. Leake, Travels in the Morea, I (London 1830) 262-3. 
of Mykonos. ${ }^{13}$ His 'signature' is in the prothesis of the church's apse, and we know that he painted two other churches in the vicinity: one at Lakedaemon on the other side of the Taygetos mountains in 1701, and Agios Ioannis Prodromos in the remote Exo Mani village of Milia in 1706. We shall return to Kalliergis. The early Ainoi paintings in Agios Nikolaos Zarnata are too fragmentary and ruined by damp to identify any coherent version of the scheme or the judges. There are however other earlier versions. The Ainoi in the katholikon of the monastery of Androubevitsa at Malta, just south of Zarnata, dated to 1704, is lacking (oddly) the zodiac and, as we shall see, is too early to have the Kritai tis gis as Venetian and Turk - if anything, the relevant section of this Ainoi, painted during the Venetokratia by Anagnostis Makromallos, shows people making representation to church elders. A contemporaneous Aino $i$ scheme in the church of the Koimisis tis Theotokou at Ligourio in the Argolid dated to 1701, again during the Venetian period, is lacking any reference to, or depiction of, the judges. In Mani there is also an earlier version of the Ainoi in the church of Agia Sofia at Gournitsa, which is tentatively dated to the seventeenth century; the condition of the Aino $i$ judges is occluded by generations of candle smoke, but again it is clear that we are not looking at the Venetian and Ottoman religious judge or cadi.

I have identified twenty-three extant versions of the Ainoi in Mani (see Fig. 2). There may be examples I have missed, and probably a significant number of others where the paintings have been whitewashed over or have disappeared, either due to damp or, in two likely cases in Doloi, to an earthquake in 1944. Of these twenty-three versions, fifteen at least have the variation of the krites as Turk and Venetian, and of these, the majority are strictly dated to a period from the mid-1740s to the late 1780 s.

With a significant proportion of the eighteenth-century paintings of the Ainoi in Mani we are fortunate to know both the names of their makers and the dates of their completion. Probably the earliest depiction of the Turk and Venetian is in the church of Agios Georgios in the village of Mirsini (or Panitsa) in Kato Mani, and, according to an inscription on the wall, is by Anagnostis of Langada and Nikolaos of Nomitsi and dates from 1746. The name Anagnostis is probably neither a true first name nor surname but an ecclesiastical honorific. He worked as a team with the aforementioned Nikolaos of Nomitsi, a village some two kilometres north of Langada, and they painted at least six other versions of the Ainoi containing the Western and Turkish judges theme and one delightful little 'signature' of their work is the inclusion of a pair of hares, chased by two small dogs amongst the 'beasts of the earth'. Anagnostis and Nikolaos are named in dedicatory inscriptions at the church of John Chrysostom at Skoutari in 1750 (where they also left useful instructions on the upkeep of the paintings) and the katholikon of the monastery of Roussaki near Kalianeika in 1758 (see Fig. 3). Stylistic similarities lead one to the conclusion that this team painted the Ainoi scheme at Agioi Theodoroi at Kambos, dated to 1760 , and those at Limeni, Agios Vasileios at Kelefa and two churches in Milia, all

13 H. Delyanni-Doris, 'Die Wandmalereien des 15. Jahrhunderts in Ajios Nikolaos in Zarnata', in Festschrift für Klaus Wesel. Münchener Arbeiten zur Kunstgeschichte und Archäologie, Band 2 (Munich 1988) 57-85. 


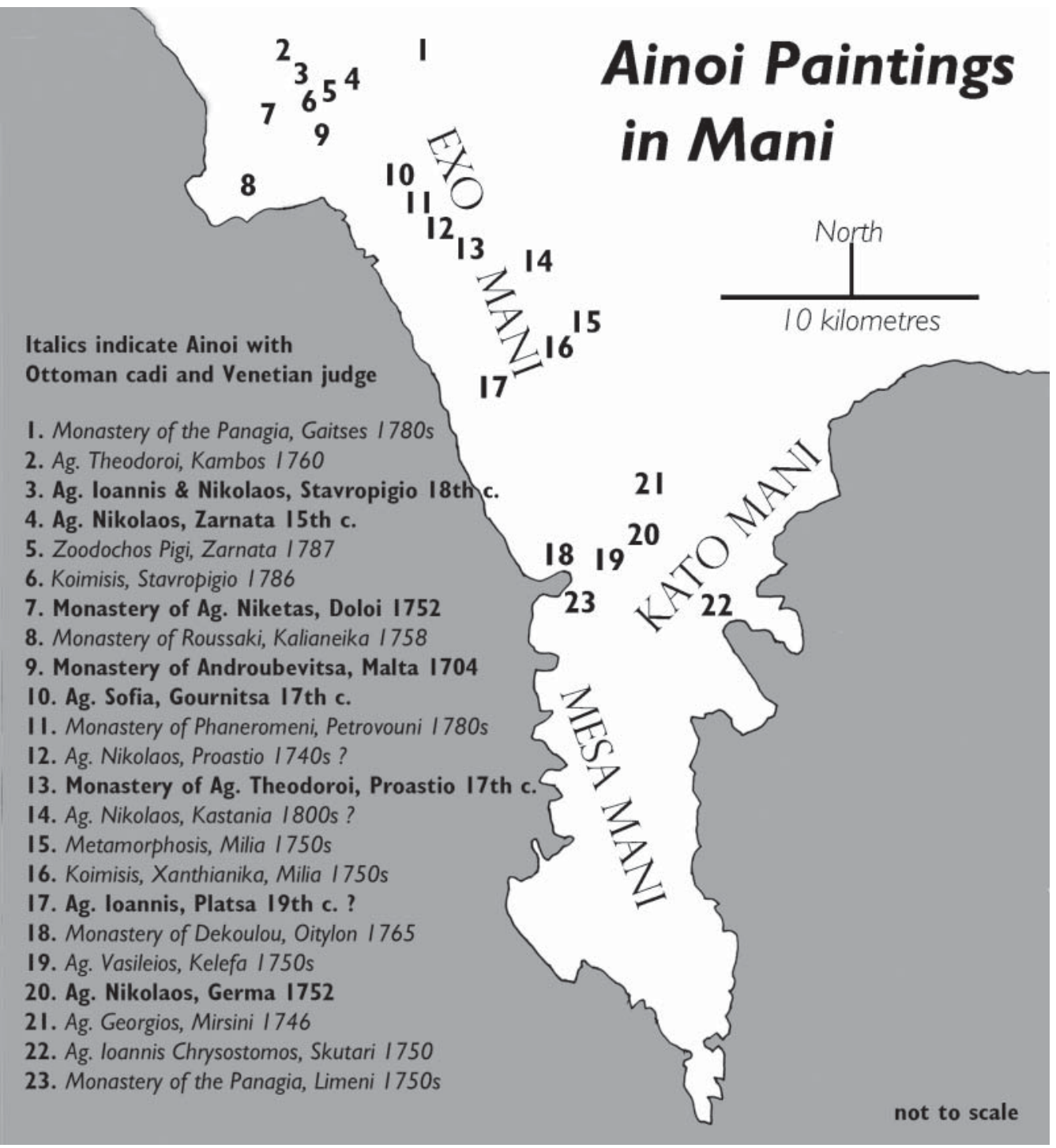

Figure 2 Map of locations of Ainoi wall paintings in Mani

in the same time-frame. There are two other versions featuring the Turk and Venetian from this mid-century period. One is in the church of Agios Nikolaos in Proastio. Here the paintings are thought to be by Anagnostis Selemperdakis of Koutifari (there was an inscription, now gone) who is also named in an inscription, along with Nikolaos of Nomitsi, as the painter of the nearby Agia Triada painted in $1745^{14}$ and Drandakis

14 For a full analysis of Agia Triada see G. Prinzing, 'Geschriebenes neben Gemaltem: zu den Memorial- und Stifterinschriften in der Kirche Hagia Triada (1743-1745) in Proasteio (Exo Mani/Peloponnes)', in S. Kolditz and R. Müller (eds), Geschenes und Geschriebenes: Studien zu Ehren von Günther S. Henrich und Klaus-Peter Matschke (Leipzig 2005) 223-51. 

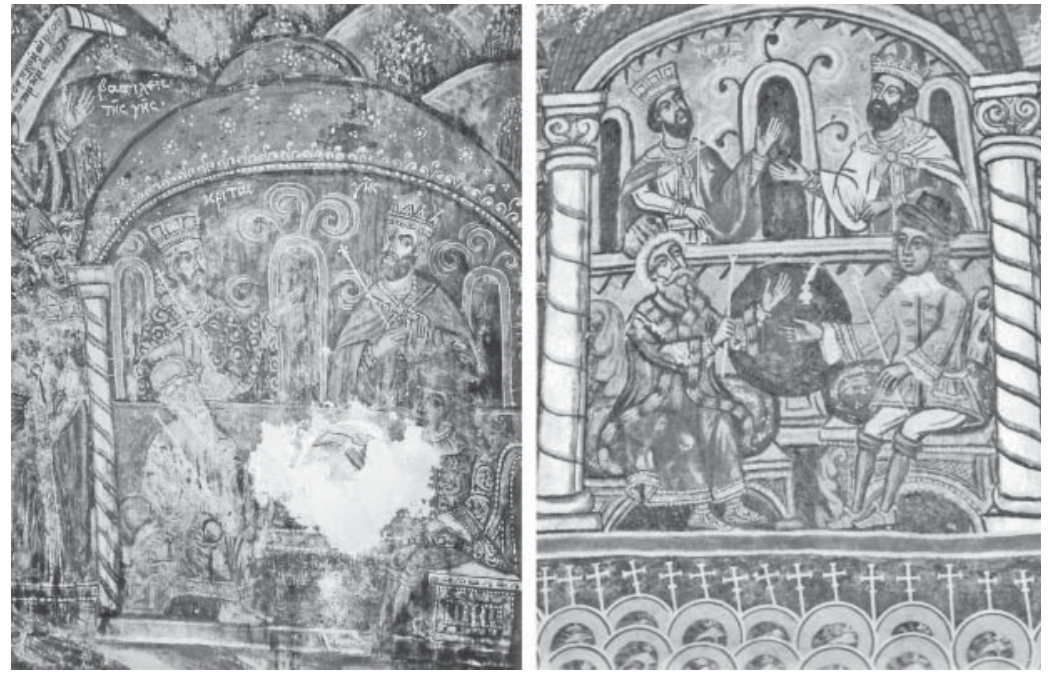

Figure 3 The Judges of the Earth. Mid-eighteenth-century generation of painters. Left: Agios Georgios, Mirsini (Panitsa) 1746. Right: monastery of Roussaki, Kalianeika, 1758

suggests Selemperdakis may be one and the same painter as Anagnostis of Langada ${ }^{15}$ (the villages are neighbours, though whether their inhabitants would want to be conflated in this manner is debatable). Another version of the theme is to be found in Dekoulou Monastery below Oitylo, painted in 1765 by Anagnostis Demangeleas of Koutifari, a family name that still persists in that locale.

Not all Ainoi of this mid-eighteenth century period include the Turk and Venetian. The isolated monastery church of Agios Nikitas near Doloi, painted in 1752 by the painters Christodoulos Pentichorakis and Parthenios Chaidemenakis of Gaitses, has the temple where the judges and their canopy would be. This feature of the temple, and no sign of the judges, is repeated in the Ainoi paintings in the southern nave of the twin church of Agios Nikolaos and Ioannis Prodromos in Stavropigio by unknown artists. There is also an Ainoi dated 1752 in the narthex of Agios Nikolaos at Germa by one Michail Klirodetis, possibly of Kelefa. Various generations of his family were actively involved in church painting during the eighteenth century in the Malevri area of Kato Mani, but at Germa there is no reference to the judges.

A generation later, in the 1780s, there is a manifestation of the Aino $i$ with the Ottoman and Venetian judges in northern Exo Mani by the team of Anagnostis Kalliergakis (or Kalliergis) of Proastio and Philippakis of Androuvitsa (a collection of settlements based roughly on the present day village of Exohori). One can speculate that the former was a descendant of the Kalliergis family from Mykonos who repainted the church of Agios Nikolaos in Zarnata castle during the early years of that century, although the name, not unknown elsewhere in post-Byzantine wall painting, merely means something 


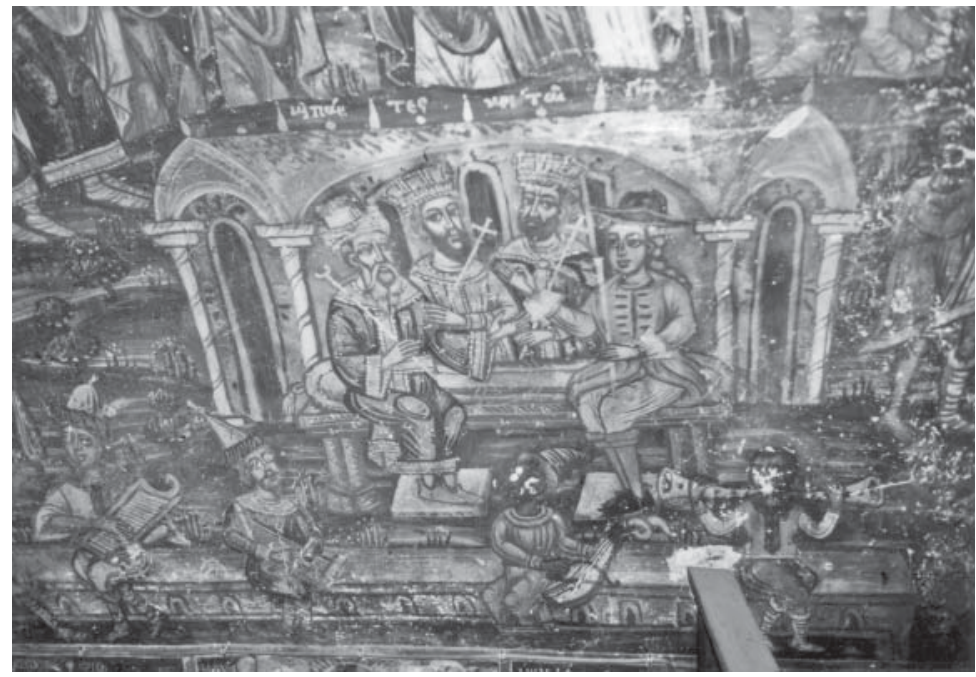

Figure 4 The Judges of the Earth and musicians. 1780s generation of painters. Church of the Koimisis tis Theotokou, Stavropigio (Varousi) 1786

akin to 'good maker'. The family name still continues in Exochori, some few kilometres from Proastio. This team painted the Aino $i$ in two churches in and just below Zarnata castle; the Zoodochos Pigi in 1787 and the Koimisis tis Theotokou the year earlier, in 1786, both of which have dedicatory inscriptions (see Fig. 4). Without inscriptions, but so similar in style as to be firmly identified with the same pair, are wall paintings, including the Ainoi, at the monasteries of the Panagia of Chelmos near Gaitses and the Phaneromeni at Petrovouni above Kardamyli. There was probably another version of the Aino $i$ in the church of Agios Nikolaos in Kato Doloi (1785), where these painters were joined by Poulos Demangeleas (presumably of Koutifari) and Pentichorakis of Gaitses. The dedication was recorded by Sokrates Kougeas in the $1930 \mathrm{~s},{ }^{16}$ but it and the paintings in the barrel vault of the church were unfortunately destroyed in a major earthquake in 1944. It was possibly from Demangeleas that they picked up on the patterns of the Ainoi, although this 1780s manifestation of the scheme is different in several minor details to those they would have seen, and studied, by the mid-century generation of painters.

The styles of all these Mani painters have little intrinsic artistic value and are naive and stereotypical, even 'comic-strip' in conception (reputedly, to be described as looking as if one had been painted by someone from Koutifari was an insult, not a compliment). ${ }^{17}$ The Venetian is depicted in anachronistic clothing, never quite of the Venetokratia, nor of the time when they were painted. For example, his wig is usually much longer than those actually prevalent in contemporaneous Western society and the cut of his coat is often several decades astray and sometimes even has short sleeves and, in the mid-century

17 F. Gearing and M. Georgota, From the Edge of Greek Space: Exo Mani (Athens 2002) 223. 
variations, short tails. The earlier generation of painting teams either took turns in the depiction of the judges or varied their depictions. The colour of his coat varies between brown, red, blue, white and yellow, and is sometimes decorated with ornate embroidery and sometimes more simple frogging. The hat has a high crown, low crown, a rolled brim or four upturned corners. Paintings of the second generation always depict the Venetian in a long yellow frock coat (perhaps taken from the earlier generations' chosen colour at the Monastery of Roussaki in 1759) and his hats are (inept) approximations of tricorns. These inaccuracies could be due to the fact that Westerners were not a common sight in eighteenth-century Mani. John Morritt reported as late as 1795, 'We ... enjoyed not a little being stopped by our guides in some of the villages with an apology that the Maniotes had never seen a stranger, and they wished to show their friends so new a sight. ${ }^{38}$

There are two more interpretations of the judges, both in Exo Mani. At Kastania in the church of Agios Nikolaos a rather striking if naively wooden style of painting shows the Aino $i$ judges on the south rather than the usual north ceiling of the nave. They are not dated, but must be no earlier than the late eighteenth century. The church has a date of 1788 carved externally near the door, and my inclination is to date the paintings to the early nineteenth century, as it has few stylistic similarities with any of the usual mid- to late eighteenth-century suspects. The Turkish cadi is clear enough but the Westerner is hard to make out because of damp and decay. He wears no hat, and appears to be in canonical dress but cannot be Orthodox as he is clean-shaven. The other oddity is in Agios Ioannis at Platsa. Here the Aino $i$ is in the conventional Western barrel vault but the church is a hotchpotch of elements. There are ancient columns and medieval spolia and at least two different painting styles, and no commentator can come up with any convincing dates, save putting both building and painting during the Turkokratia. Here the judges have only one king behind them and are dressed identically with strange pointed caps and look like clerks of a court. The style is extremely crude and idiosyncratic and more like other local naif nineteenth-century wall paintings than the formulaic eighteenth-century examples.

As Garidis commented, 'Il est évident que pour le cas de la peinture à l'échelle locale du village et la region, on ne dispose pas d'éléments suffisants pour soutenir que le phénomène de regression de la peinture savante vers une peinture populaire est un phénomène particulier à l'époque.' 19 There was also an increase in themes of real life and popular beliefs. The three themes which gave opportunities for these to flourish, and which are more prevalent in post-Byzantine painting, were the Last Judgement, the Akathistos Hymn and the Ainoi. As Garidis himself proposed, 'nous essaierons d'étudier l'évolution de l'élément profane dans la peinture religieuse'.20

Petronotis has identified these mid-eighteenth-century church painters as 'The School of Koutifari'. ${ }^{21}$ The name Koutifari belongs to both a family (sometime kapetanoi of

19 Garidis, Etudes sur le Jugement Dernier. 14.

20 Ibid., 19.

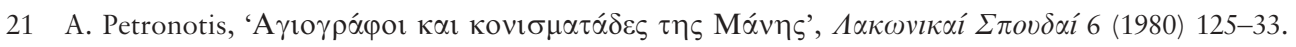


Zarnata) and a village some ten kilometres south, now renamed Thalames after its ancient name Thalamai, and it is to this location that Petronotis is alluding. The appellation 'school' is, as is commonly the case, a later invention, and in fact the painters of this period whom we can identify by name came from a variety of Exo Mani villages: Gaitses and Androuvitsa in the north, Proastio in the centre, and Nomitsi, Koutifari and Langada in the south. One therefore has the impression less of an aesthetic or pedagogic 'school' than of a district's artistic reaction to the prosperity of Exo Mani in the mid-eighteenth century.

A combination of factors, namely relative independence, unrestricted trade in olive oil, valonea and prinokoki (dyes from the local holm oak trees), rampant piracy and minimal taxation, meant that there was money to spare for conspicuous religious patronage in the kapetanoi-dominated villages of Exo and Kato Mani. ${ }^{22}$ The Maniates' religious fervour was remarked upon by many observers and the sheer number of mid- to late eighteenth-century wall paintings (easily recognizable even though only a minority are attributed or dated) reveals families, villages and monasteries with cash to spare for hiring teams of local painters either to decorate newly built churches or in other cases to repaint or overpaint previous schemes. Sir William Gell noted at Kallithea in Exo Mani in 1804, 'a new chapel, which is the more observable as this is a rare occurrence in any part of Turkey'. ${ }^{23}$ Another example is the church of the Zoodochos Pigi just below the summit of the castle of Zarnata, which has an inscription over the north side door celebrating the fact that it was founded in 1780 with donations from the surrounding villages of Varousi (present day Stavropigio) and Malta and was built by craftsmen from neighbouring Androuvitsa. It was then painted seven years later along with the larger Koimisis tis Theotokou church just below, which was built in 1748 .

The similarity in these painters' oeuvres, which demonstrates this vigorous, if naif, style, can be put down to a number of factors and probably has as much to do with the prevalent use of manuals, pattern books and stencils as with any organized 'school'. Oddly for such a thorough prescription of post-Byzantine wall-painting schemes, The Painter's Manual of Dionysius of Fourna has little or nothing to say on the subject of the Ainoi, and there are enough variations in the various Mani Ainoi schemes to show that whereas there was an overall shape to the frescos the painters had room for personal reinterpretation. ${ }^{24}$ What is clear is that the scheme seems to have enjoyed a vogue in mid-eighteenth-century Mani, and that the depictions of the Ottoman and the Venetian as judges are restricted to a half century from the mid-1740s onward and were painted by locals rather than outsiders.

What was the political context of this phenomenon? The oft-heard claim that Mani was free and left to its own devices by the Ottomans throughout the Tourkokratia is at

22 J.M. Wagstaff, 'The economy of the Mani peninsula (Greece) in the eighteenth century', Balkan Studies

6/2 (1965) 293-304.

23 W. Gell, Narrative of a Journey in the Morea (London 1823) 254.

24 The Painter's Manual of Dionysius of Fourna, tr. P. Hetherington (London 1977). 
best a doubtful assertion and at worst wishful thinking. As the antipathetic Sir William Gell commented, 'It appeared that notwithstanding the boasts of freedom the whole business was a compromise, into which the Turks had entered to save themselves the trouble of an exterminating war and the Greeks for the sake of having no foreigner in the country. ${ }^{25}$ The far more philhellenic George Finlay was also sceptical: 'It is said that Maina never submitted to a foreign conqueror. Though the assertion is repeated by many writers of authority, it is a vulgar error. It might, perhaps, be said with greater truth, that order and justice never reigned in Maina.'26

What seems clear is that the Ottoman hold on Mani was always de jure, but de facto tenuous and episodic. However, after the fall of Crete in 1669, the Ottoman forces made a concerted effort to subjugate Mani in 1670, as chronicled by Evliya Celebi, who accompanied the occupying Ottoman forces. ${ }^{27}$ The success of this occupation was demonstrated not just by their rebuilding and garrisoning of the forts at Zarnata, Kelefa and Passava, but also by the effect that the imposition of Ottoman rule had on Maniat communities. In this period, when Turkish law and taxation were firmly enforced and piracy, a mainstay of Maniat economic life, was presumably stifled, there were considerable emigrations to Italy, Corsica and Sardinia from the recently prosperous communities of Oitylo and Proastio.

This period was relatively brief, for in the mid-1680s the Venetians replaced the Turks as rulers of the Peloponnese, including Mani. In the case of the fall of the recently refurbished castle of Zarnata, in September 1685, the Venetians, under Morosini, were enthusiastically assisted by the local Maniates. Even with a new and at first conciliatory governance by the Venetians, there are the usual stories pertaining to the Maniates' timehonoured refusal to pay taxes or submit to census. ${ }^{28}$ However, it is clear that the Venetians set up three provinces in Mani, namely, Passava, Kelefa and Zarnata, and by the early 1700 s they had assiduously surveyed and carried out censuses and were collecting taxes from all quarters of Mani. ${ }^{29}$

The Venetians, and mainly, it must be admitted, their burdensome bureaucracy, proved so unpopular with the Maniates that on 15 August 1715 they met the advancing Ottoman troops of Vezir Ali Pasha. As Benjamin Brue, who accompanied the Ottoman forces, observed: 'ce même jour, il arriva au camp deux Evesques et plusieurs Grecs, tous Maïnotes, députez de la haute et basse Maïne, qui forment ensemble un espèce de République, pour se soumettre à la Porte et demander sa protection' ${ }^{30}$ The Maniates also offered to persuade the Venetians at Zarnata and Kelefa to surrender, which the Venetians, and their mostly mercenary troops, hastily did.

25 Gell, Narrative of a Journey in the Morea, 262.

26 G. Finlay, A History of Greece, V (Oxford 1877) 113.

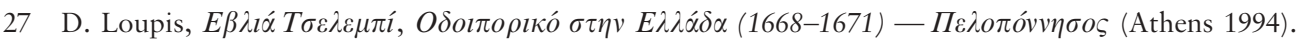

28 P. Topping, 'Premodern Peloponnesus: the land and the people under Venetian rule (1685-1715)', in Studies on Latin Greece AD 1205-1715 (London 1977).

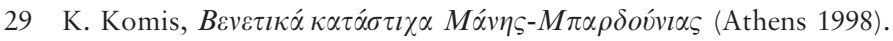

30 B. Brue, Journal de la campagne que le gand vesir Ali Pasha a faite en 1715 pour la conquête de la Morée (Athens 1976; reprint of Paris 1870 ed.) 37. 
Thus we have the Maniates first enthusiastically assisting the Venetians to eject the Ottomans and then, thirty years later, equally enthusiastically conniving to oust the Venetians and negotiate a separateness from the Ottoman power, if not complete independence. The Maniates paid a small levy or haratch and remained under nominal Ottoman governance. It seems slightly improbable that they would, thirty-five years later, make the personification of the legal power of those empires a centrepiece of wall paintings in some of their largest parish and monastery churches.

As already mentioned, the mid-eighteenth-century Ainoi paintings in Mani are restricted to the northern parts of the peninsula. There appear to be no depictions further south than Skoutari in the east and Limeni on the west coast. This is underlined by the scarcity of eighteenth-century frescos in the Deep Mani and the relative contemporaneous poverty of that area. (For instance, olives, a perennial mainstay of Exo Mani's economy, were not introduced into Mesa Mani until the latter half of the nineteenth century.) Yet there is another, very obvious, visual factor which marks the difference between Deep Mani and the rest of Mani in the eighteenth century.

In Ottoman-dominated Greece it was illegal to ring church bells or construct bell towers. These strictures were probably never as draconian as the letter of the law might suggest, and, rather like the rule forbidding non-Muslims to ride horses, could often be ignored, as there was always room for bribery. However, there are a large number of bell towers, or campaniles, in Mani and very few in the rest of the Peloponnese. These telescopic structures are particularly prevalent in Exo Mani, more often than not as additions and afterthoughts to previous church buildings, and are usually copiously covered with folkloric carvings and reliefs and the date of construction. The kapetanoi-dominated settlements of Mani were generally religiously corporate, and it is usual that the central church (itself often of eighteenth-century origin) in each location was graced by these visual expressions of Maniat independence. There is a boast, which can still be heard today, that the Turks 'never silenced the bells of Mani'.

In Mesa Mani there is a relative dearth of these soaring campaniles, the only eighteenth-century example (and then very late) being in Areopolis (then Tzimova), which was dominated by the Mavromichalis clan, and in the area around Gytheion, the purlieu of the Grigorakis family. This is presumably because of the geo-social division of Mani into the kapetanoi-dominated Exo and Kato Mani and the more fractured societal mores and extreme poverty of Mesa Mani. The kapetanoi were dominant in areas where villages were religiously corporate, reflecting the endogamous nature of this society. The eighteenth-century Mesa Mani was, in stark contrast, an exogamous society, intermarriage being banned to seven degrees of kinship, villages divided into warring families, with concomitant concentration on small family chapels. Building and painting large central churches needs both wealthy patronage and a willing and large congregation. The earliest separate campanile of note in the Mesa Mani is at Ochia and dates to as late as 1861 , and only in the last decade of the twentieth century was there the will and money to build a large central church in the notoriously squabblesome Mesa Mani village of Kita.

The depiction of the 'Judges of the Earth' as Turkish cadi and Venetian was a deliberate interpretation by certain groups of mid-eighteenth-century Maniat painters and 
directed at a broad communal audience in the relatively independent, oligarchic and wealthy Exo and Kato Mani. We know relatively little of the detail of legal mores in Mani during the eighteenth century, but can confidently speculate that there was no formal legal system as such. Even before the Turkish incursion of 1670 the Venetian Francesco Morosini had written of Mani in 1659, 'the inhabitants live without specific legal institutions, without rules of government, deprived of administration and leadership'. ${ }^{31}$ After the interim forty-five years of Ottoman then Venetian rule, it is likely that Mani reverted to its old customs, except that in Exo and Kato Mani the kapetanoi system, established by the Venetians, provided local hegemonies.

In 1786 an anonymous Frenchman wrote to his Foreign Office,

Le Magne n'a et ne s'auroit avoir de loix ecrittes; le peuple s'en rapporte dans les discussions qu'il peut avoir, quand la force n'en a pas décidé, à la sagesse et au jugement des vieillards; leurs chefs même ne jouissent de l'honneur de les juger que lorsqu'ils l'ont obtenu par l'âge. Ces capitaines ... n'ont nulle autre authorité et nulle distinction extérieure. ${ }^{32}$

Some few years later, Dimo and Nicolo Stephanopoli, uncle and nephew from Corsica (and who could claim lineage from the emigrants to that island from Oitylo in 1675) visited Mani in the late 1790s as envoys of Napoleon Bonaparte, who nurtured Levantine ambitions, soon to be briefly fulfilled in Egypt. The pair were, in their 'ghosted' recollections, inordinately fond of depicting the Maniates as freedom-loving republican descendants of the ancient Spartans, but even their revolutionary zeal could not conceal the fact that there was no law in Mani: 'Chez eux, point de notaires, point d'hommes de loi, et par conséquent point d'huissiers." 33 Disregarding the observation that eighteenth-century Maniates were spared the afflictions of bailiffs, it is clear that legal processes were crude and arbitrary; as the Stephanopoli remarked, 'S'il s'élevait un procès, les parties s'addressaient à un arbitre, qui, pour l'ordinaire, était un vieillard: son jugement était sans appel.'34 Thomas Parnell, Consul for the Dutch in Patras, confirms this impression. In a report to his employers dated 1817 he described the Maniates as 'peuple accoutumé à l'indépendance et à la piraterie, ne connaissant ni loi ... ils ont constamment vecû et vivront toujours dans la plus grande anarchie'. ${ }^{35}$ William Martin Leake, perhaps the most assiduous observer, both temperamentally and due to the fact he was working as an agent of the British Foreign Office, wrote of the Maniates in a letter and memorandum to Lord Harrowby (3 May 1805): 'Their internal disputes, which arise from a want of any other law than that of the lex talionis, render it necessary for every man to go armed with

31 K. Mertzios, in Y. Saitas, Greek Traditional Architecture: Mani (Athens 1990) 23.

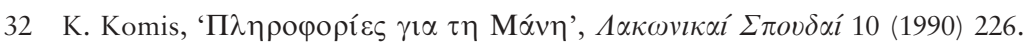

33 D. and N. Stephanopoli, Voyage de Dimo et Nicolo Stephanopoli en Grèce, II (Paris 1799) 39.

34 Ibid., 200.

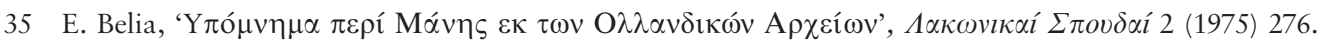


musquet or with a dagger or pistols. ${ }^{36}$ Any form of codified law, such as that of the Byzantine Hexabiblos, as Tourtoglou points out, was not introduced to Mani until the Kapodistrian era, and even then had to be imposed under duress. Only in the 1830s were regular courts established in Mani. ${ }^{37}$

Certainly the evidence of early nineteenth-century Western visitors tends to confirm the impression that the kapetanoi acted as local tyrants. Sir William Gell observed after his visit in March 1804 of the Maniates: 'Under a hundred captains they are a hundred times more oppressed than they would be under the worst despotism of the Turks. ${ }^{38}$ Admittedly Gell was hardly sympathetic to the Greeks in general (for which views he was lambasted and castigated by the Edinburgh Review on the publication of his book Narrative of a Journey in the Morea in $1823^{39}$ ) and he heaped a fair amount of opprobrium on the Maniates, but this was also the conclusion of the more empathic Charles Cockerell in 1812 who wrote of his stay at Kardamyli with Panayotis Mourtzinos, Kapetanios of Androuvitsa: 'In no part of Europe at any rate, if indeed in the world, could one find such singular scenes or come upon a state of society so exactly like that of our ancient barons ... The whole gave us a picture of feudal life new and hardly credible to a nineteenth century Englishman. ${ }^{40}$ This is further stressed by John Morritt who, after his 1795 visit to Exo Mani, wrote of the kapetanoi: 'They were perfectly independent of each other; the judges of their people at home, and their leaders when they took the field. ${ }^{41}$

With such capricious and arbitrary rule, is it not likely that some inhabitants of Exo and Kato Mani would have regretted the disappearance of a (relatively) neutral legal structure that brought some sort of impartiality to the inter-village and inter-family feuding which appear to have been endemic to the area? The 1750 s generation of painters in Mani would have certainly heard stories of Venetian justice (doubtless alleviated by tales of oppressive bureaucracy) and, as for the Turkish cadis, they were within reportable distance. Kalamata was only a few kilometres from the northern Maniat border at Almyros, and John Bramsen reported in 1818 on his journey from Gytheion to Mistra coming across a village in Vardounia close to Mani's north-east borders (probably Agios Nikolaos) where the dominating castle was the home of the local judges. ${ }^{42}$

There are hints that the Venetians kept some sort of influence in Mani, if only over trading matters. Pouqueville, writing in the early 1800s, reported that the Consul-General,

36 The National Archives (TNA): Public Record Office (PRO): Leake to Lord Harrowby, 3 May 1805, FO

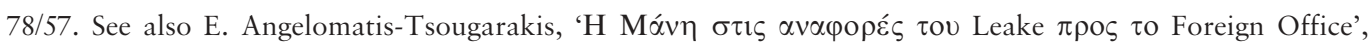

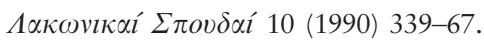

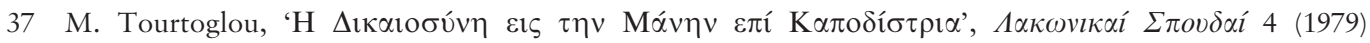
$213-29$.

38 Gell, Narrative of a Journey in the Morea, 268.

39 Edinburgh Review 38/76 (May 1823) 314-32.

40 C. Cockerell, Travels in Southern Europe and the Levant 1810-1817 (London 1903) 96-7.

41 J. Morritt, in R. Walpole, Memoirs Relating to European and Asiatic Turkey, and Other Countries of the East (London 1817) 40.

42 J. Bramsen, Travels in Egypt, Syria, Cyprus, the Morea, Greece, Italy etc. etc., II (Edinburgh 1820) 39. 
who seems to have sorted out all sorts of external problems in Mani, was still under the standard (pavillon) of the Venetians. ${ }^{43}$ But this doesn't appear to have extended to common law and therefore still begs the question why, when painters came to interpret the last Psalms in their wall paintings, they did not depict their own ruling families the Troupakis-Mourtzinos of Androuvitsa, Christeas of Zygos, Dourakis of Kastania, Koumoundouros of Zarnata, Grigorakis of Mavrovouni and Ageranos or the Mavromichalis of Limeni, who were the reality of law in eighteenth-century Mani - and why instead they used the despised Muslim Turks and Catholic Venetians to represent the 'Judges of the Earth'. What message was this projecting?

The painters of many of the Ainoi schemes were stern moralists. Almost de rigueur in their paintings was a warning to the local papas with the depiction in the sanctuary, under the prothesis, of a priest in contemporary dress being swallowed by the Great Beast and an accompanying inscription identifying this unfortunate as the 'foolish and heretical Arius'. As mentioned by Garidis and part of his observed trend toward more profane themes in post-Byzantine wall painting, they were equally fond of adding a bottom layer of paintings to the churches they decorated. To the rear of the nave and therefore clearly intended for the laity was a vivid 'comic-strip' depiction of what happened to sinners. In extremely crude and explicit frescos the tortures of hell were offered to the downward gaze of the congregation. Horned, winged, tailed and trident-wielding devils prodded homosexuals, let loose snakes on a prostitute's pudenda, hung up cheating millers using their own millstones for weights. These painters were clearly not averse to making a graphic moral point. And if the worshippers at the west end of the nave were to raise their eyes, in a mixture of supplication and relief, to more spiritual things they would still get a vision of the world they inhabited, with local women dancing to the music of local musicians in local costumes. And in the centrepiece, framed emphatically by a canopy, were the 'Judges of the Earth'. Not locals at all.

One could speculate that the painters were being merely literal, depicting those who last exemplified a formal legal system in Mani, with the religious import of the paintings uppermost. But there was no need to include the judges at all. Not all the verses of Psalms 148-150 are depicted and the judges, as we have observed, are sometimes missing. Their inclusion is an expression of nostalgia for past times of legal stability and some form of justice and as such hardly squares with the populist legends of a fiercely and proudly independent Mani. Is it not highly likely that the depiction of the Ottoman and Venetian judges, members and potent symbols of occupying powers in Mani, was a vivid political comment indicting the contemporary lawless nature of Mani by those who suffered under the arbitrary despotic powers of the kapetanoi, and, further, that the local Mani wall painters of the mid-eighteenth century, who were first and foremost communicators, knew they had a captive audience from religiously corporate communities who would not have failed to take the graphic point?

43 F. Pouqueville, Voyage en Morée, à Constantinople, en Albanie, et dans plusiers autres parties de l'empire othoman, pendant les années 1798, 1799, 1800 et 1801, II (Paris 1805) ii-xv. 